\title{
Innovative Breast Cancer Biomarkers
}

\author{
Angelo Paradiso $^{a}$ Rosella Silvestrini ${ }^{b}$ Gennaro Chiappetta ${ }^{c}$ \\ a National Cancer Centre, Bari, \\ ${ }^{\mathrm{b}}$ Istituto Oncologico Romagnolo, Meldola (FO), \\ ${ }^{\mathrm{c}}$ Fondazione G Pascale Istituto Tumori, Napoli, Italy
}

The enormous technological developments characterizing the last decades of cancer research made possible the interpretation of several biological phenomena peculiar of cancer cells. However, after many efforts in the search for clinical application of this know-how in terms of new biomolecular markers for risk, prognosis, and prediction of therapeutic efficacy still only few examples of their utilization in clinical practice are available. One reason for this could be the lack of translation into routine practice; other frequently cited reasons are the low quality of the validation studies performed so far [1] and the need for an optimization of the process leading the biomarker from basic research to clinical practice [2].

Aware of this situation, the Italian Ministry of Health in 2007 supported the development of a national concerted action aimed at developing a specific pathway for 'analytical and clinical validation of new biomarkers for cancer diagnosis and outcome prediction'. The supported action clustered 37 national research teams, involved in different biomarker studies and interested in generating a coordinating body where expertise in methodologies, statistical analysis, quality control, and biological resources to perform validation studies for new cancer biomarkers were concentrated. The action, coordinated by the National Cancer Institute (NCI) - Istituto Tumori Bari, started in 2007 and activated 7 projects, each of which focused on specific tumors and disease-specific biomarker studies [2].

One of these, the project 'biomarkers of female cancers', was aimed at promoting the development of technologies for isolating and characterizing circulating cancer cells in breast cancer patients, and validating the use of a panel of markers for circulating cancer cell detection to improve the accuracy of cancer staging, prognosis, and as a rapid assessment of therapeutic response. Several groups are involved in this project:

1) The Unit of the Istituto Nazionale Tumori Fondazione Pascale, Naples (Dr. G. Chiappetta), analyzes the high mobility group A (HMGA) protein overexpression in the serum of patients with operable breast cancer, patients with metastatic breast cancer, and subjects without evidence of can- cer. HMGA proteins (HMGA1a, HMGA1b, HMGA2) are an abundant class of nuclear factors that play an important role in regulating the transcription of a large number of genes [3]. Aim of this project is to validate these proteins as markers for early cancer cell detection and to improve the accuracy of cancer staging and prognosis, possibly leading to a rapid assessment of therapeutic response.

2) The Unit of the Istituto Nazionale per la Ricerca sul Cancro of Genoa (Dr. M. Romani), examines the potential application of circulating nucleic acids, both DNA and RNA, as a breast cancer biomarker for early diagnosis and for the evaluation of the patients' prognosis.

3) The Unit of the Casa Sollievo della Sofferenza, San Giovanni Rotondo, Foggia, seeks to evaluate the analytical and clinical validation of methylation status determination in serum obtained from breast cancer patients to detect new prognostic indicators. The detection of breast cancer in the early stages is the key for a successful treatment of the disease and preliminary data from this team suggest that the methylation distribution pattern changes during mammary tumor progression, with some genes being methylated in the early stages of tumor development while other genes are methylated later [4].

4) The Clinical Experimental Oncology Laboratory of the National Cancer Institute 'Giovanni Paolo II', Bari, proposed a study on the involvement of $\mathrm{Na}^{+} / \mathrm{H}^{+}$exchanger regulatory factor (NHERF1) in the genesis and progression of cancer: this team reported an interesting pathological role for this protein based on its altered subcellular delocalization and interaction with tyrosine kinase receptors [5].

In this Issue, these topics are reviewed by the principal investigators of these projects considered of particular potential clinical interest.

\section{Acknowledgement}

Partially supported by Ministry of Health - Italian Government, 'Programma Integrato Oncologia (PIO) 2007'.

\section{KARGER}

Fax +497614520714

Information@Karger.de

www.karger.com
(C) 2010 S. Karger GmbH, Freiburg

Accessible online at:

www.karger.com/brc
Angelo Paradiso, $\mathrm{MD}, \mathrm{PhD}$

Direzione Scientifica

Istituto Tumori ‘Giovanni Paolo II', National Cancer Centre

Via Hahnemann, 10, 7016 Bari, Italy

+39080 5555-482 fax -139

a.paradiso@oncologico.bari.it 


\section{References}

1 McShane LM, Altman DG, Sauerbrei W, Taube SE, Gion M, Clark GM; Statistics subcommittee of NCI-EORTC working group on cancer diagnostics: reporting recommendations for tumor marker prognostic studies (REMARK). Breast Cancer Res Treat 2006;100:229-235.

2 Paradiso A, Mangia A, Orlando C, Verderio P, Belfiglio M, Marchetti A, Bertario L, Chiappetta G, Gion M, Tonini GP, Podo F, Vocaturo A, Silvestrini R, Romani M, Belloni E, Cavallo D, Ulivi P, Tommasi S, Steffan A, Russo A, Alessio M, Calistri D, Zancan M, Parrela P, Broggini M, Giuseppe A, Buttitta F, Finocchiaro G, Mazzocco K, Veronesi G, Landuzzi L, Benevolo M, Mariani L, De Marco F, Venuti A, Giannelli G, Quaranta M, Trojano V: The Integrated Oncology Program of the Italian Ministry of Health. Analytical and clinical validation of new biomarkers for early diagnosis: network, resources, methodology, quality control, and data analysis. Int J Biol Markers 2009;24:119-129.

-3 Chiappetta G, Ottaviano A, Vuttariello E, Monaco M, Galdiero F, Gallipoli A, Pilotti S, Jodice G, Siranoush M, Colombo M, Ripamonti CB, Pallante PL, Radice P, Fusco A: HMGA1 protein expression in familial breast carcinoma patients. Eur J Cancer 2010;46:332-339.

4 Hoque MO, Prencipe M, Poeta ML, Barbano R, Valori VM, Gallo AP, Copetti M, Brait M, Maiello E, Apicella A, Rossiello R, Zito F, Stefania T, Paradiso A, Carella M, Dalla Piccola B, Murgo R, Carosi I, Bisceglia M, Fazio VM, Sidransky D, Parrella $\mathrm{P}$ : Changes in $\mathrm{CpG}$ islands promoter methylation patterns during ductal breast carcinoma progression. Canc Epidem Biomar Prev 2009;18:2694-2700.

5 Mangia A, Chiriatti A, Bellizzi A, Malfettone A, Stea B, Zito FA, Reshkin SJ, Simone G, Paradiso A: Biological role of NHERF1 protein expression in breast cancer. Histopathology 2009;55:600-608. 